\title{
Effect of Growth Stimulants on Morphological and Phenological Parameters of Okra (Abelmoschus esculentus L.) cv. Arka Anamika under Soil test Based Nutrient Management System
}

\author{
K.S. Vishnu* and G.V. Sudarsana Rao \\ Department of Plant Physiology, College of Horticulture, Vellanikkara, Kerala Agricultural \\ University, 680656, Kerala, India \\ *Corresponding author
}

\begin{abstract}
A B S T R A C T
An investigation on effect of growth stimulants on morphological and phenological parameters of Okra (Abelmoschus esculentus L.) cv. ArkaAnamika under soil test based

Keywords

Growth stimulants,

Okra, Soil test

based nutrient

management

Article Info

Accepted:

10 July 2018

Available Online:

10 August 2018 nutrient management system was conducted at Central nursery, College of Horticulture, Vellanikkara, Kerala Agricultural University, Kerala, during September-December, 2016. The experiment was laid out in a randomized block design (RBD) with fifteen treatments in three replications. The okra (Abelmoschus esculentus L.) cv. ArkaAnamika was raised as per standard package of practices recommendations of Kerala Agricultural University and also under soil test based nutrient management system. Foliar applications of growth stimulants were given at 15, 30 and 45 days after sowing (DAS). The morphological and phenological parameters such as plant height, leaf area per plant, leaves per plant, branches per plant, days to $50 \%$ flowering, days to first harvest and duration of crop were significantly influenced by the growth stimulants application and soil test based nutrient management. The use of growth stimulants such as humic acid, cytozyme, and potassium silicate with soil test based modified nutrient management system improve the morphological parameters like plant height, leaf area per plant and the number of leaves per plant than control. Among the four growth stimulants used, humic acid performed better followed by cytozyme and potassium silicate.
\end{abstract}

\section{Introduction}

Okra or bhindi (Abelmoschus esculentus L.) commonly known as lady's fingers, belongs to the family Malvaceae. It is one of the important summer vegetable crops grown widely in sub-tropical regions of the world for its tender pods. The plant requires warm temperature and is unable to withstand low temperature for long or tolerate any threat of frost. Ideal temperature is in the range of 21 $30^{\circ} \mathrm{C}$, with minimum of $18^{\circ} \mathrm{C}$ and maximum of $35^{\circ} \mathrm{C}$ respectively. Okra has good potential as a foreign exchanger crop and accounts for $65 \%$ export of fresh vegetables. In India it is cultivated in $0.35 \mathrm{mha}$ area with a production of $3.5 \mathrm{mt}$ and productivity of $9.6 \mathrm{mt} / \mathrm{ha}$. The major okra producing states are Uttar Pradesh, Bihar, Orissa, West Bengal, Andhra Pradesh and Karnataka (FAOSTAT, 2011). Okra 
production and productivity is significantly affected due to the use of low yielding local varieties, sub-optimal plant density, in appropriate planting dates, soil fertility, attack of various insect pests and weeds etc. Ideal plant population and nitrogen fertilizer dose are the two essential key elements for enhancing the profitability in okra (Chadha, 2002).

In the present scenario of agriculture, the extent to which farmers can depend on chemical fertilizers is constrained by its increasing cost and availability at right time. Moreover, fertilizer recommendation of crops based on soil test data is an important criterion to enhance nutrient use efficiency. To attain sufficient and sustainable yield to meet the demand for food, different strategies to increase the efficiency of chemical fertilizers are investigated. One approach to enhance productivity of crop is the development of environment friendly growth stimulants which have beneficial effects on plants.

The soluble organic molecule contained in the growth stimulants has direct effect on metabolic and physiological processes of plants due to their particular molecular structure. Growth stimulants influence plant growth by modifying the physiology of plants and by improving the physical, chemical and biological properties of soil. Growth stimulants, an elixir to plants have long been recognized by the scientists for its influence on the growth and development of crops (Ertani et al., 2015).

Growth stimulants influence on physiology of plants for enhancing the growth, yield and quality. Be that as it may, the component behind the physiological and biochemical impacts of the growth stimulants on products is as yet obscure. Therefore, further research on the influence of growth stimulants is proposed to explore the impact of them on morphological and phenological parameters of okra variety ArkaAnamika under soil test based modified nutrient management system.

\section{Materials and Methods}

The experiment was conducted at Central nursery, College of Horticulture, Vellanikkara, Kerala Agricultural University, Kerala during September-December, 2016. The experiment was laid out in a randomized block design (RBD) with fifteen treatments in three replications. The plot size was $3 \mathrm{~m} \times 2.4 \mathrm{~m}$ $\left(7.2 \mathrm{~m}^{2}\right)$. The crop was raised as per standard package of practices recommendations (PoP) of Kerala Agricultural University (KAU) and also under soil test based nutrient management system.

Experiments consisted of 15 treatments viz., standard PoP, KAU $\left(\mathrm{T}_{1}\right)$ as control, soil test based modified nutrient management $\left(\mathrm{T}_{2}\right), \mathrm{T}_{1}$ + humic acid spray @ $0.2 \%\left(\mathrm{~T}_{3}\right), \mathrm{T}_{1}+$ potassium silicate spray @ $0.3 \%\left(\mathrm{~T}_{4}\right), \mathrm{T}_{1}+$ cytozyme spray@0.2\% ( $\left.\mathrm{T}_{5}\right), \mathrm{T}_{1}+$ putrescine spray@50 ppm $\left(\mathrm{T}_{6}\right), \mathrm{T}_{2}+$ humic acid spray @ $0.2 \%\left(\mathrm{~T}_{7}\right), \mathrm{T}_{2}+$ potassium silicate spray @ $0.3 \%\left(\mathrm{~T}_{8}\right), \mathrm{T}_{2}+$ cytozyme spray @ $0.2 \%\left(\mathrm{~T}_{9}\right)$, $\mathrm{T}_{2}+$ putrescine spray @50 ppm $\left(\mathrm{T}_{10}\right), 50 \% \mathrm{~T}_{1}$ + humic acid spray @0.2\% $\left(\mathrm{T}_{11}\right), 50 \% \mathrm{~T}_{1}+$ potassium silicate spray @ $0.3 \%\left(\mathrm{~T}_{12}\right), 50 \%$ $\mathrm{T}_{1}+$ cytozyme spray @ $0.2 \%\left(\mathrm{~T}_{13}\right), 50 \% \mathrm{~T}_{1}+$ putrescine spray @ 50 ppm $\left(\mathrm{T}_{14}\right)$ and water spray $\left(\mathrm{T}_{15}\right)$.

To ascertain physio-chemical characteristics of the soil during the season of study, soil samples from $0-15 \mathrm{~cm}$ depth were collected from different locations of the experimental field before application of fertilizers. The experimental field was thoroughly ploughed and the soil was brought to a good tilth. The area was ploughed and levelled. The plot size adopted was $7.2 \mathrm{~m}^{2}$ ( $\left.3 \mathrm{~m} \times 2.4 \mathrm{~m}\right)$. Plots of $3 \mathrm{~m} \mathrm{x}$ $2.4 \mathrm{~m}$ were made by taking bunds of $25 \mathrm{~cm}$ width and height. Secondary and 
micronutrients were applied as per soil test data except in treatments $\mathrm{T}_{1}, \mathrm{~T}_{3}, \mathrm{~T}_{4}, \mathrm{~T}_{5}, \mathrm{~T}_{6}$, $\mathrm{T}_{11}, \mathrm{~T}_{12}, \mathrm{~T}_{13}$ and $\mathrm{T}_{14}$. Soil test data showed that, soil was acidic in nature and elements like magnesium, boron and sulphur were deficient. $\mathrm{CaCO}_{3} @ 350 \mathrm{Kgha}^{-1}, \mathrm{MgSO}_{4} @ 80 \mathrm{Kg}$ $\mathrm{ha}^{-1}$ and Borax@10 $\mathrm{kgha}^{-1}$ was applied to soil for correcting the soil nutrient status. At the time of sowing $\mathrm{N}, \mathrm{P}_{2} \mathrm{O}_{5}$ and $\mathrm{K}_{2} \mathrm{O} @ 55,35$ and $70 \mathrm{~kg} \mathrm{ha}^{-1}$ was applied. Another $55 \mathrm{~kg} \mathrm{Nha}^{-1}$ applied one month after sowing. After basal fertilizer application, the seeds were dibbled at a spacing of $60 \times 60 \mathrm{~cm}$ at the rate of $7 \mathrm{kgha}^{-1}$. Foliar spraying of growth stimulants was done at 15,30 and 45DAS.

Intercultural operations and hand weeding were carried out in okra crop to maintain weed free condition during crop season. The crop was free from major insect pests and diseases by taking suitable plant protection measures. Five plants were randomly selected from each plot and tagged permanently. Morphological and phenological observations such as plant height, number of leaves per plant, leaf area per plant, number of branches per plant, days to $50 \%$ flowering, days to first harvest and duration of crop were recorded at $25^{\text {th }}$ and $50^{\text {th }}$ days after sowing.

The recorded data were subjected to statistical analysis using the Web Agri Stat Package (WASP). Multiple comparisons among treatment means, where the $\mathrm{F}$ test was significant (at $5 \%$ level) were done with Duncan's Multiple Range Test.

\section{Results and Discussion}

\section{Soil characters before the experiment}

The data on soil characters (Table 1) revealed that soil was acidic in nature and the elements like magnesium, sulphur and boron were deficient in the experimental field.
Plant height $(\mathrm{cm})$ and leaf area per plant $\left(\mathrm{cm}^{2}\right)$

The data regarding the plant height $(\mathrm{cm})$ and leaf area per plant $\left(\mathrm{cm}^{2}\right)$ at 25DAS and 50DAS are presented in Table 2. It shows that plant height influenced significantly with application of foliar spraying of growth stimulants.

The plant height at 25DAS was analyzed statistically to observe pairwise difference among the treatments. The post hoctest using $\mathrm{CD}$ revealed that treatment $\mathrm{T} 8$ had contributed to the maximum plant height $(25.46 \mathrm{~cm})$. Plant height under the treatments T9 $(24.41 \mathrm{~cm}), \mathrm{T} 7$ $(24.14 \mathrm{~cm}), \mathrm{T} 10(23.29 \mathrm{~cm}), \mathrm{T} 3(21.69 \mathrm{~cm}), \mathrm{T} 5$ $(21.56 \mathrm{~cm}), \mathrm{T} 4(21.47 \mathrm{~cm}), \mathrm{T} 2(20.85 \mathrm{~cm}), \mathrm{T} 6$ $(20.76 \mathrm{~cm}), \quad \mathrm{T} 11 \quad(20.36 \mathrm{~cm})$ and $\mathrm{T} 13$ $(20.18 \mathrm{~cm})$ were on par with that of T8 $(25.46 \mathrm{~cm})$. The lowest plant height was recorded with the treatment $\mathrm{T} 1(13.50 \mathrm{~cm})$.

At 50DAS, maximum height was observed in the treatment $\mathrm{T} 7(90.75 \mathrm{~cm})$ followed by $\mathrm{T} 9$ $(88.36 \mathrm{~cm})$ and $\mathrm{T} 8(85.79 \mathrm{~cm})$. Treatment $\mathrm{T} 15$ $(75.46 \mathrm{~cm})$ and $\mathrm{T} 1(75.56 \mathrm{~cm})$ were on par with that of $\mathrm{T} 2(75.66 \mathrm{~cm})$ and the treatments $\mathrm{T} 5$ $(77.76 \mathrm{~cm})$ and $\mathrm{T} 4(77.83 \mathrm{~cm})$ were on par with that of treatment $\mathrm{T} 3(79.20 \mathrm{~cm})$. The lowest plant height was recorded for treatment $\mathrm{T} 14(65.00 \mathrm{~cm})$.

A perusal of data (Table 2) showed that leaf area differed significantly with application of different growth stimulants. The application of humic acid spray along with soil test based modified nutrient management resulted in significantly higher value of leaf area (398.83 $\left.\mathrm{cm}^{2}\right)$ followed by T9 $\left(386.71 \mathrm{~cm}^{2}\right)$ and T8 $\left(380.40 \mathrm{~cm}^{2}\right)$. Treatment T8 $\left(380.40 \mathrm{~cm}^{2}\right)$ was on par with that of treatment T9 $\left(386.71 \mathrm{~cm}^{2}\right)$ and the treatment T1 $\left(294.81 \mathrm{~cm}^{2}\right)$ was on par with that of T15 $\left(295.52 \mathrm{~cm}^{2}\right)$. Treatment T14 was recorded the lowest leaf area (236.25 $\mathrm{cm}^{2}$. 
On the $50^{\text {th }}$ day the maximum leaf area was observed in treatment $\mathrm{T} 7\left(979.11 \mathrm{~cm}^{2}\right)$ followed by the treatment T9 $\left(793.02 \mathrm{~cm}^{2}\right)$, this was significantly higher than that of the treatments T8 $\left(775.86 \mathrm{~cm}^{2}\right)$, T10 $\left(756.76 \mathrm{~cm}^{2}\right)$ and T3 $\left(735.35 \mathrm{~cm}^{2}\right)$. The lowest value was observed in treatment T14 $\left(432.91 \mathrm{~cm}^{2}\right)$.

Morphological parameters of control (T1) plots were recorded on par with that of water sprayed (T15) plots. An increase in 20.10 per cent plant height was recorded in treatment $\mathrm{T} 7$ (Soil test based modified nutrient management with humic acid spray@0.2\%) followed by 16.94 percent in T9 (Soil test based modified nutrient management with cytozyme spray@0.2\%) and 13.53 percent in T8 (Soil test based modified nutrient management with potassium silicate spray@0.3\%) compared to control. The plants which received 50 per cent standard PoP along with growth stimulants recorded minimum plant height. Among different sets of treatments, soil test based nutrient management with growth stimulants application resulted higher plant height than treatments receiving standard $\mathrm{PoP}$ with growth stimulants followed by 50 percent standard PoP with growth stimulants (Figure 1).
Among the growth stimulants, humic acid performed better followed by cytozyme, potassium silicate and putrescine. A similar pattern of effectiveness of growth stimulants was observed in the case of number of leaf area per plant.

\section{Number of leaves per plant and number of branches per plant}

On $25^{\text {th }}$ DAS the treatment $\mathrm{T} 7$ had contributed to the maximum number of leaves per plant (8.40) followed by T9 (7.43) and T8 (7.13). Treatment T5 (6.40) was on par with that of T4 (6.26) and T10 (6.03) was on par with T3 (6.00). Treatment T13 (5.33) was on par with that of T12 (5.36). The minimum number of leaves per plant was obtained in the T14 (5.10) treatment.

On the $50^{\text {th }}$ day the maximum number of leaves per plant was observed in treatment $\mathrm{T} 7$ (25.20) followed by the treatment T9 (23.66), this was significantly higher than that of the treatments T8 (20.20), T6 (19.03) and T5 (17.26). In treatments T15 (13.40), and T1 (13.40) similar values of number of leaves was recorded.

Fig.1 Percentage variation of plant height $(\mathrm{cm})$ from control

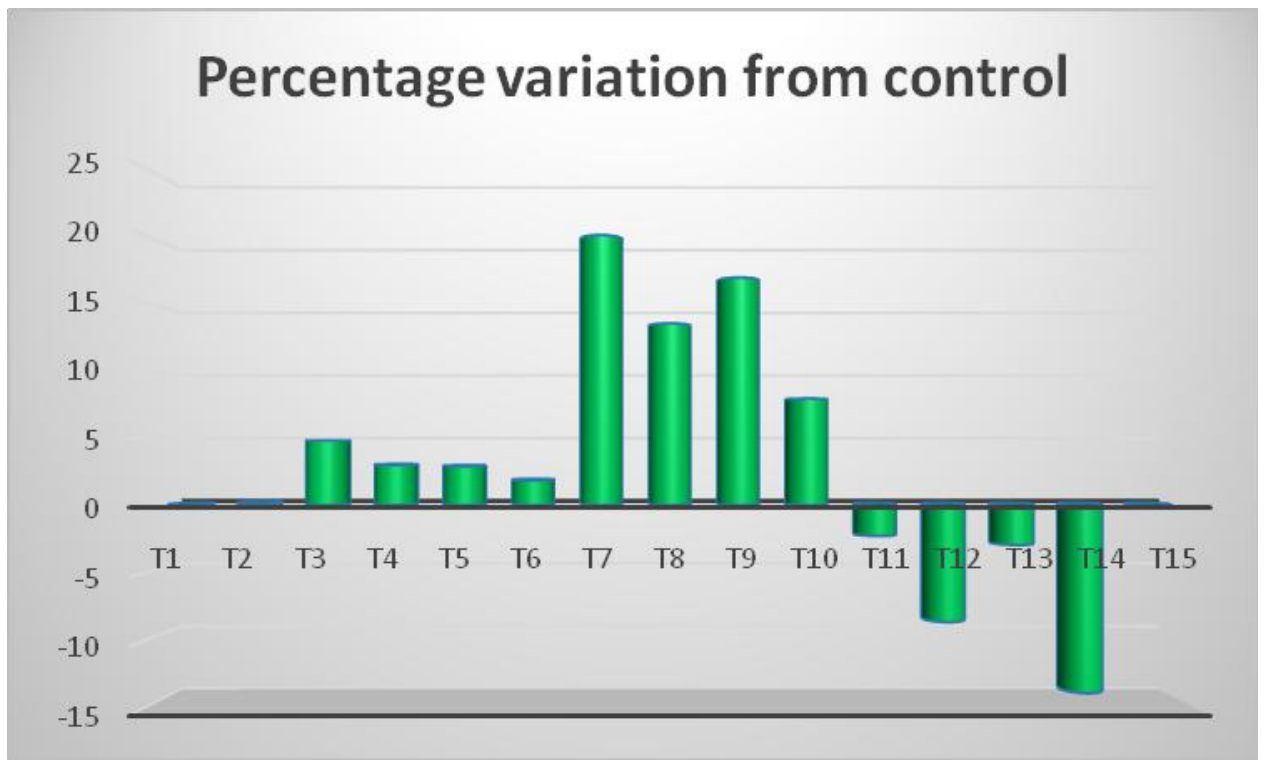


Table.1 Soil characters before the experiment

\begin{tabular}{|l|c|c|}
\hline Parameters & Quantity & \multicolumn{1}{|c|}{ Remarks } \\
\hline $\mathrm{pH}$ & 5.3 & Strongly Acidic \\
\hline Electrical Conductivity (dS/m) & 0.04 & Normal \\
\hline Organic Carbon $(\%)$ & 0.86 & Medium \\
\hline Available Nitrogen $(\mathrm{Kg} / \mathrm{ha})$ & 80.23 & Medium \\
\hline Available Phosphorus(Kg/ha) & 67.23 & High \\
\hline Available Potassium(Kg/ha) & 308.00 & High \\
\hline Available Calcium(mg/kg) & 785.00 & Sufficient \\
\hline Available Magnesium(mg/kg) & 65.30 & Deficient \\
\hline Available Sulphur(mg/kg) & 3.91 & Deficient \\
\hline Micronutrients & & \\
\hline Copper(mg/kg) & 5.92 & Sufficient \\
\hline Iron $(\mathrm{mg} / \mathrm{kg})$ & 116.90 & Sufficient \\
\hline Zinc $(\mathrm{mg} / \mathrm{kg})$ & 2.9 & Sufficient \\
\hline Manganese $(\mathrm{mg} / \mathrm{kg})$ & 34.03 & Sufficient \\
\hline Boron $(\mathrm{mg} / \mathrm{kg})$ & 0.04 & Deficient \\
\hline
\end{tabular}

Table.2 Effect of various growth stimulants on plant height $(\mathrm{cm})$ and leaf area per plant $\left(\mathrm{cm}^{2}\right)$

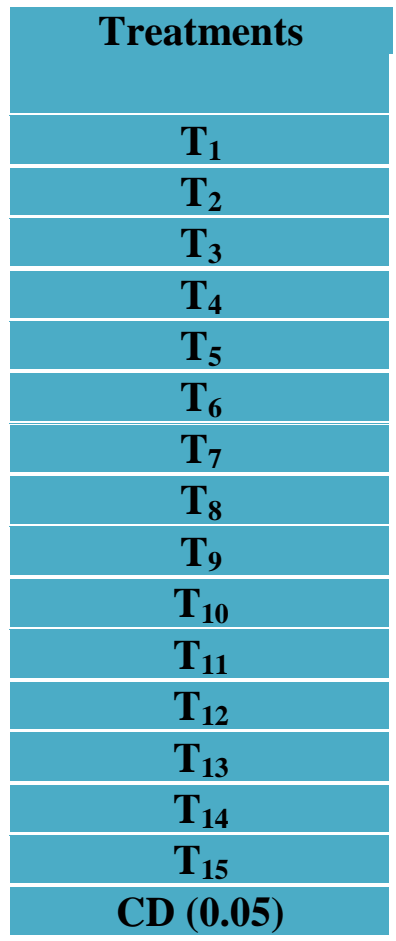

\begin{tabular}{|c|c|c|c|}
\hline \multicolumn{2}{|c|}{ Plant height (cm) } & \multicolumn{2}{|c|}{ Leaf area $\left(\mathbf{c m}^{2}\right)$} \\
\hline 25 DAS & 50 DAS & 25 DAS & 50 DAS \\
\hline 13.50 & 75.56 & 5.70 & 13.40 \\
\hline 20.85 & 75.66 & 5.86 & 13.50 \\
\hline 21.69 & 79.20 & 6.00 & 16.00 \\
\hline 21.47 & 77.83 & 6.26 & 15.80 \\
\hline 21.56 & 77.76 & 6.40 & 17.26 \\
\hline 20.76 & 76.96 & 6.73 & 19.03 \\
\hline 24.14 & 90.75 & 8.40 & 25.20 \\
\hline 25.46 & 85.79 & 7.13 & 20.20 \\
\hline 24.41 & 88.36 & 7.43 & 23.66 \\
\hline 23.29 & 81.56 & 6.03 & 14.00 \\
\hline 20.36 & 73.83 & 5.43 & 13.00 \\
\hline 18.84 & 69.00 & 5.36 & 12.73 \\
\hline 20.18 & 73.33 & 5.33 & 11.70 \\
\hline 18.14 & 65.00 & 5.10 & 10.63 \\
\hline 16.70 & 75.46 & 5.76 & 13.40 \\
\hline 5.88 & 1.73 & 0.28 & 1.77 \\
\hline
\end{tabular}


Table.3 Effect of various growth stimulants on number of leaves per plant and number of branches per plant

\begin{tabular}{|c|c|c|c|c|}
\hline Treatments & \multicolumn{2}{|c|}{ Number of leaves per plant } & \multicolumn{2}{|c|}{ Number of branches per plant } \\
\hline & 25 DAS & 50 DAS & 25 DAS & 50 DAS \\
\hline $\mathbf{T}_{\mathbf{1}}$ & 1.06 & 2.66 & 294.81 & 615.00 \\
\hline $\mathbf{T}_{\mathbf{2}}$ & 1.06 & 2.86 & 306.03 & 659.68 \\
\hline $\mathbf{T}_{\mathbf{3}}$ & 1.06 & 3.10 & 356.05 & 735.35 \\
\hline $\mathbf{T}_{\mathbf{4}}$ & 1.13 & 3.46 & 332.01 & 697.15 \\
\hline $\mathbf{T}_{\mathbf{5}}$ & 1.06 & 3.76 & 345.76 & 720.28 \\
\hline $\mathbf{T}_{\mathbf{6}}$ & 1.00 & 4.06 & 320.45 & 685.51 \\
\hline $\mathbf{T}_{\mathbf{7}}$ & 1.46 & 4.56 & 398.83 & 979.11 \\
\hline $\mathbf{T}_{\mathbf{8}}$ & 1.26 & 4.20 & 380.40 & 775.86 \\
\hline $\mathbf{T}_{\mathbf{9}}$ & 1.33 & 4.33 & 386.71 & 793.02 \\
\hline $\mathbf{T}_{\mathbf{1 0}}$ & 1.13 & 2.93 & 373.63 & 756.76 \\
\hline $\mathbf{T}_{\mathbf{1 1}}$ & 1.13 & 3.26 & 279.50 & 583.80 \\
\hline $\mathbf{T}_{\mathbf{1 2}}$ & 1.13 & 2.50 & 256.65 & 492.75 \\
\hline $\mathbf{T}_{\mathbf{1 3}}$ & 1.13 & 2.40 & 270.90 & 543.67 \\
\hline $\mathbf{T}_{\mathbf{1 4}}$ & 1.00 & 2.00 & 236.25 & 432.91 \\
\hline $\mathbf{T}_{\mathbf{1 5}}$ & 1.00 & 2.70 & 295.52 & 618.33 \\
\hline $\mathbf{C D}(\mathbf{0 . 0 5})$ & $\mathrm{NS}$ & 0.48 & 7.77 & 16.14 \\
\hline
\end{tabular}

Table.4 Effect of various growth stimulants on phenological characters

\begin{tabular}{|c|c|c|c|}
\hline Treatments & $\mathbf{5 0 \%}$ flowering (days) & First harvest (days) & Duration of crop (days) \\
\hline $\mathbf{T}_{\mathbf{1}}$ & 35.66 & 41.66 & 94.00 \\
\hline $\mathbf{T}_{\mathbf{2}}$ & 34.00 & 40.00 & 96.33 \\
\hline $\mathbf{T}_{\mathbf{3}}$ & 33.66 & 39.66 & 97.00 \\
\hline $\mathbf{T}_{\mathbf{4}}$ & 35.66 & 41.66 & 93.33 \\
\hline $\mathbf{T}_{\mathbf{5}}$ & 36.00 & 42.00 & 99.00 \\
\hline $\mathbf{T}_{\mathbf{6}}$ & 37.00 & 43.00 & 100.00 \\
\hline $\mathbf{T}_{\mathbf{7}}$ & 30.33 & 36.33 & 96.66 \\
\hline $\mathbf{T}_{\mathbf{8}}$ & 32.66 & 38.66 & 95.33 \\
\hline $\mathbf{T}_{\mathbf{9}}$ & 33.66 & 39.66 & 95.00 \\
\hline $\mathbf{T}_{\mathbf{1 0}}$ & 35.00 & 41.00 & 99.33 \\
\hline $\mathbf{T}_{\mathbf{1 1}}$ & 33.66 & 39.66 & 94.33 \\
\hline $\mathbf{T}_{\mathbf{1 2}}$ & 35.33 & 41.33 & 95.66 \\
\hline $\mathbf{T}_{\mathbf{1 3}}$ & 36.00 & 42.00 & 94.33 \\
\hline $\mathbf{T}_{\mathbf{1 4}}$ & 35.00 & 41.00 & 92.33 \\
\hline $\mathbf{T}_{\mathbf{1 5}}$ & 37.66 & 43.66 & 93.00 \\
\hline $\mathbf{C D}(\mathbf{0 . 0 5}$ & 1.08 & 1.08 & 1.95 \\
\hline
\end{tabular}


The number of leaves per plant under the treatments T15 (13.40), T1 (13.40) and T11 (13.00) was on par with that of T12 (12.73). The lowest number of leaves per plant was observed in treatment of T14 (10.63).

Application of different growth stimulants significantly influenced the number of branches (Table 3). On 25 DAS, the maximum number of branches (1.46) per plant was recorded with treatment $\mathrm{T} 7$ and the minimum number of branches of per plant was obtained from the treatments T14 (1.00) and T15 (1.00). On 50DAS, the maximum number of branches per plant was observed in treatment $\mathrm{T} 7$ (4.56) and T9 (4.33) followed by the treatment $\mathrm{T} 8$ (4.20) this was significantly higher than that of the treatments T6 (4.06) and T5 (3.76).

The beneficial effect of humic acid on plant growth might be due the better uptake of micronutrients from soil to plant. Effects of humic acid appear to be mainly on cell membrane properties and it act as hormonelike substances. These results are inconformity with the findings of Clapp et al., (2001) and Ghorbani et al., (2010).

Potassium silicate improves the vegetative growth characters, nutrient uptake and distribution. The results are in agreement with the findings of Ali et al., (2011) and Cheng, (1982). Foliar application of cytozyme and putrescine also enhanced the morphological characters of okra. Cytozyme increased photosynthetic efficiency on account of stabilization of chlorophyll and higher production of photosynthates resulting in increased secondary branches simultaneously. Cytozyme increase $\mathrm{CO} 2$ fixation and chlorophyll contents of leaves and improved leaf area. These results are in accordance with findings of Rana and Vashistha (1998). Putrescine application in plants improve the cell ionic condition, maintenance of membrane integrity, prevention of chlorophyll loss and improvement in synthesis of protein, nucleic acids and protective alkaloids (Kusano et al., 2008).

\section{Phenological characters}

A critical examination of data (Table 4) revealed that days to $50 \%$ flowering were affected significantly by different growth stimulants application. Treatment T15 (37.66) took more days to complete $50 \%$ flowering and this was on par with the treatments T6 (37.00). Treatments T4 (35.66), T12 (35.33), T10 (35.00), T14 (35.00) were statistically on par with that of treatment T1 (35.66). Treatments T9 (33.66) and T11 (33.66) were on par with that of T3 (33.66). Treatment T7 (30.33) took minimum days to complete $50 \%$ flowering.

The highest numbers of days to first harvest was recorded with treatment T15 (43.66) which was on par with T6 (43.00). In treatments T3, T11 and T9 similar values (39.66) of number of days for first harvest was recorded. Treatments T4 (41.66), T12 (41.333), T10 (41.00), T14 (41.00) were statistically on par with that of treatment $\mathrm{T} 1$ (41.66). Treatment T13 (42.00) was on par with that of T5 (42.00). The least numbers of days to first harvest was recorded with treatment T7 (36.33).

The duration of crop was highest with treatment T6 (100.00) which was on par with T10 (99.33) and T5 (99.00). In treatments T11 and T13 (94.33) similar crop duration was recorded. Treatments T8 (95.33), T12 (95.66), T2 (96.33) and T7 (96.66) were on par with that of T3 (97.00). The minimum duration was recorded with treatment T14 (92.33).

Among the 15 treatments, T7 (Soil test based modified nutrient management with humic 
acid spray @ $0.2 \%$ ) recorded least number of days to 50 per cent flowering followed by T8 (Soil test based modified nutrient management with potassium silicate spray @ $0.3 \%$ ). A similar pattern was also observed in the case of number of days to first harvest. Significant superiority over control might be due to increased photosynthetic activity and uptake of food nutrients resulting in early flowering as reported by Patel et al., (2009) in bhendi.

This implicated that soil test based nutrient management practices with growth stimulants gave a significant factor for improving the plant phenological characters and which would influence on the yield parameters also.

\section{References}

Ali, A., Tahir, M., Amin, M., Basra, S. M. A., Maqbool, M., and Lee, D. J. 2011. Silicon induced stress tolerance in wheat hydroponically grown under water deficit conditions. J. Agric. Sci. 19(5): 951-957.

Chadha, K.L. 2002. Hand Book of Horticulture. Indian Council of Agricultural Research, New Delhi, 427p.

Cheng, B.T. 1982. Some significant functions of silicon to higher plants. J. Plant Nutr. 5: 1345-1353.

Clapp, C.E., Chen, Y., Hayes, M.H.B., and Cheng, H.H. 2001. Plant growth promoting activity of humic substances. In: Swift, R.S. and Sparks, K.M. (ed),
Understanding and Managing Organic Matter in Soils, Sediments and Waters $\left(11^{\text {th }}\right.$ Edn.). International Humic Science Society, Madison, pp. 243-255.

Ertani, A., Smbo, P., Nicoletto, C., Santagata, S., Sachiavon, S., and Nardi, S. 2015. The use of organic biostimulants in hot pepper plants to help low input sustainable agriculture. Chem. Biol. Technol. Agric. 11(2): 252-256.

FAOSTAT [Food and Agricultural Organization of the United Nations production statistics]. 2011. [online] Available: http://fao.org). [17 May2011].

Ghorbani, S., Khazaei, H.R., Kafi, M., and Banayanl, M. 2010. The effect of adding humic acid to irrigation water on yield and yield components of corn. $J$. Agric. Ecol. 2: 123-131.

Kusano, T., Berberich, T., Tateda, C., and Takahashi, Y. 2008. Polyamines: essential factors for growth and survival. Biol. Plant. 228: 367-381.

Patel, A. P., Tandel, Y.N., Patel, C.R., Patel, M.A., and Patel, P.B. 2009. Effect on combined application of organic manures with inorganic fertilizers on growth and yield of okra cv. parbhanikranti. Asian J. Hortic.4(1):7881.

Rana, B. S. and Vashistha, R.N. 1998. Effect of various chemical on growth and yield characteristics of radish (Raphanus sativus L.). Haryana J. Hort. Sci., 14(2): $97-101$

\section{How to cite this article:}

Vishnu, K.S. and Sudarsana Rao, G.V. 2018. Effect of Growth Stimulants on Morphological and Phenological Parameters of Okra (Abelmoschus esculentus L.) cv. Arka Anamika under Soil test Based Nutrient Management System. Int.J.Curr.Microbiol.App.Sci. 7(08): 1658-1665. doi: https://doi.org/10.20546/ijcmas.2018.708.190 